\title{
A new species of Echium (Boraginaceae) from the island of Porto Santo (Madeira Archipelago)
}

\author{
by \\ José Augusto Carvalho ${ }^{1}$, Tânia Pontes ${ }^{2}$, Maria Isabel Batista-Marques ${ }^{3} \&$ Roberto Jardim $^{4}$ \\ ${ }^{1}$ Jardim Botânico da Madeira Eng. ${ }^{\circ}$ Rui Vieira, Caminho do Meio, 9064-512 Funchal, Portugal; \\ ${ }^{2}$ Rua João de Paiva 5, 3. ${ }^{\circ}$ Direito, 1400-225 Lisboa, Portugal; ${ }^{3}$ ESOD, Rua do Freixeiro, 4434-506 Vila Nova de Gaia, Portugal; \\ ${ }^{4}$ Centro de Ciências da Vida, Universidade da Madeira, 9000-390 Funchal, Portugal \\ josecarvalho.sra@gov-madeira.pt; rjardim@netmadeira.com
}

\begin{abstract}
Abstratc
Carvalho, J.A., Pontes, T., Batista-Marques, M.I. \& Jardim, R. 2010. A new species from the island of Porto Santo (Madeira Archipelago). Anales Jard. Bot. Madrid. 67(2): 87-96.

A new species endemic from the island of Porto Santo (Madeira Archipelago) is described as Echium portosanctensis J.A. Carvalho, Pontes, Batista-Marques \& R. Jardim. Morphological studies based on reproductive and vegetative traits revealed a set of diagnostic characters confirming separation of E. portosanctensis from other recognized species at sectional level. A taxonomic diagnosis, a morphological description and illustrations of the new species are provided. Images, distribution maps, ecological data and a key for Madeiran species of Echium are also provided. Diagnostic characters, conservation status, threats and speciation mechanisms are discussed. In addition, reports on the occurrence of $E$. candicans on the island of Porto Santo are also discussed.
\end{abstract}

Keywords: Pico Branco, Macaronesia, Echium nervosum, Echium candicans, threatened species.

\section{Introduction}

Echium (Boraginaceae), with 28 endemic species, is one of the most diverse genera in Macaronesia (Bramwell, 1972; Santos, 1983). Endemics of this genus occur in the archipelagos of Madeira, Canary and Cape Verde, thriving in many habitats, from sea level to $2300 \mathrm{~m}$. a.s.l. Morphologically they fall in four major growth forms. Because of this extraordinary morphological diversity and the ability of these species to exploit very diverse ecological niches, Macaronesian taxa of Echium form an ideal plant group to test hypothesis pertinent to the origin and evolution of some unique traits which are common on islands

\section{Resumen}

Carvalho, J.A., Pontes, T., Batista-Marques, M.I. \& Jardim, R. 2010. Una nueva especie de la isla de Porto Santo (Archipiélago de Madeira). Anales Jard. Bot. Madrid. 67(2): 87-96 (en inglés).

Echium portosanctensis J.A. Carvalho, Pontes, Batista-Marques \& R. Jardim se describe para la isla de Porto Santo (Achipiélago de Madeira). Estudios morfológicos basados en datos reproductivos y vegetativos revelan una serie de caracteres diagnósticos que confirman la separación de E. portosanctensis de otras especies de su sección. Se aportan una diagnosis taxonómica, una descripción morfológica e ilustraciones para esta nueva especie. Se presentan imágenes, mapas de distribución, datos ecológicos y una clave para las especies de Madeira. Se discuten los caracteres diagnósticos, el estado de conservación, amenazas, y los mecanismos de especiación. También se discuten datos previos sobre la presencia de E. candicans en la isla de Porto Santo.

Palabras clave: Pico Branco, Macaronesia, Echium nervosum, Echium candicans, especies amenazadas.

(García-Moroto \& al., 2009). Among these traits, the most relevant one in Echium, concerns the acquisition and significance of woodiness. Evolutionary studies using molecular markers conducted by Böhle \& al. (1996) concluded that the Macaronesian taxa of Echium are the result of colonization from a single continental-herbaceous ancestor. However, this study failed to answer questions on evolutionary patterns of inter-island colonization and plant habitat and ecological shifts (García-Moroto \& al., 2009). It was only recently that García-Moroto \& al. (2009), by using a set of molecular markers showing higher levels of molecular variation, were able to bring important and new insights into the colonization history of $\mathrm{Ma}$ - 
caronesian Echium, timing of differentiation, adaptive radiation and evolution of woodiness.

In the archipelago of Madeira species diversity is much less than that found in the Canary Islands. The most recent account on plant diversity in the archipelagos of Madeira and Selvagens (Jardim \& Sequeira, 2008) refer two arborescent endemic species of Echium, namely E. candicans L.f., a high altitude (800$1500 \mathrm{~m}$ ) species that only occurs on the island of Madeira, and E. nervosum Dryand., restricted to altitudes between 0 to $300 \mathrm{~m}$ and occurring in all main islands of the archipelago, i.e. Madeira, Porto Santo and Desertas.

Accounts of Echium L. on the island of Porto Santo date back to the early $20^{\text {th }}$ century. Menezes (1914) and Pickering (1962) refer to E. nervosum Dryand. for the site of Zimbralinho. More recently, Hansen (1969), Jardim \& al. (1998) and Jardim \& Sequeira (2008) also reported E. nervosum to Porto Santo. Costa (1946) is the first author to refer E. candicans to Porto Santo on the north of Gandaia. Later, Pickering (1962) refers to Costa's (1946) observation of $E$. candicans. Bramwell (1972) referred to a specimen of E. candicans L.f. collected by Hansen on Pico Castelo which was presumed to be cultivated or a naturalized individual that escaped from cultivation.

Andrada (1974), in his contribution for the conservation of the Madeiran flora, reported a possible novel taxon of Echium for the island of Porto Santo, and stated: "... Echium nervosum Ait. (fot. 15), do litoral da Madeira, se destaca em relação a outra espécie ou subespécie portosantense (fot. 16) pela nítida diferenciação da cor das suas inflorescências que numa são azuis com estames brancos e noutras amareladas ou branco-rosadas, devido aos estames (filetes carmim e anteras azuis)". He points out that E. nervosum clearly differs from the taxon of the island of Porto Santo because of the colour of their inflorescences; the former has a blue inflorescence with white stamens whereas this new taxon shows yellowish or pinkish-white inflorescence due to the stamens, which have carmine filaments and blue anthers. More recently, Jardim \& al. (1998) confirmed the existence of Echium cf. nervosum Dryand. on the island of Porto Santo, specifically on Pico Branco, and referred that this taxon differed from typical E. nervosum on leaf shape, texture and colour, as well as the colour of the inflorescence.

\section{Materials and methods}

Field observations and collections were carried out on the islands of Porto Santo and Madeira since 1999. Herbarium specimens are deposited at MADJ.

A set of morphological characters used by previous authors (Short, 1994; Bramwell, 1972) at species level were selected for the present study. An additional set of morphological characters was chosen for better resolving the variation along geographical distribution.

Photography of leaf indumentum was performed using a binocular magnifying glass Zeiss Stemi 2000-C and a photographic camera Canon PowerShot G6. The image was captured using the software Canon Utilities ZoomBrowser EX 5.0 version 5.0.0.142.

Distribution of studied specimens was obtained by plotting field location data, e.g. altitude and topography, onto a military map. The location obtained was then transformed into $1 \mathrm{~km}^{2}$ grid based Universal Transverse Mercator (UTM) .

\section{Results and discussion}

The genus Echium is now represented in Madeira archipelago by three endemic species: E. candicans on the island of Madeira, E. nervosum on the islands of Madeira, Desertas and Porto Santo and E. portosanctensis on the island of Porto Santo. These species are taxonomically positioned within the Macaronesian endemic sect. Virescentia [Christ ex Spr. \& Hutch.] Bramwell, showing cylindrical inflorescence, non-laterally compressed flowers, and blue or pink corolla with more or less equal lobes. Section Virescentia is the largest (10 out of 28 Echium species in Macaronesia) and the most widespread in Macaronesia (Bramwell, 1972). Species of this section occur on all Canary Islands except Lanzarote (Bramwell, 1972), and on all islands of Madeira archipelago (Bramwell, 1972; Short, 1994; Jardim \& Sequeira, 2008).

\section{Misidentified species reports on Porto Santo}

Reports of E. candicans for the island of Porto Santo (Costa, 1946; Pickering, 1962; Hansen in Bramwell, 1972; Short, 1994) are not supported either by our studies and confirm earlier accounts by Jardim \& al. (1998). We found no herbarium specimens of E. candicans collected by Costa (1946) and therefore we were unable to confirm this previous record of this taxon for Porto Santo. Bramwell's (1972) reference of E. candicans to the island of Porto Santo was based on a specimen collected by Hansen in 1967 on Pico Castelo that we were unable to find either. Moreover, in our research we came across with a herbarium specimen collected by Vieira (MADJ 05995) identified as E. candicans and reported to have been planted from seeds collected on Pico Branco. Vieira (pers. com.) wrote a letter to Hansen in 1977 asking for identification of this specimen. Hansen's opinion was it was likely that this material belonged to a garden hybrid of 
E. strictum and E. virescens, i.e. E. $\times$ fastuosum. According to Hansen (Vieira, pers. com.), the original presence of this hybrid on Pico Branco would have been the result of dispersion of seeds originated from hypothetical specimens of both species in cultivation on the island of Porto Santo. Moreover, Hansen referred to Vieira (Vieira, pers. com.) that he had collected the same hybrid on Pico Castelo, Porto Santo, in 1969. However, we were not able to trace any voucher specimen of such a collection. Vieira in disagreement with Hansen, identified the plant as a specimen of $E$. candicans. However, our observation of such herbarium specimen clearly indicates it to belong to a plant of the new species described here as E. portosanctensis.

Echium portosanctensis J.A. Carvalho, Pontes, Batista-Marques \& R. Jardim, sp. nov.

Ab E. nervosa Dryand. foliis laevibus indumento sericeo ornatis (nec asperis neque dense strigosis) adaxialiter pallide viridibus vel argenteo-viridibus atque abaxialiter griseo-albis vel argenteis (nec pallide viridibus), ambitu longitudinali ordinis foliorum late angulatoovati atque ad latera superiora recto, foliis superioribus saepe cymas laterales aequantibus (nec quam eis multo brevioribus) atque lingulatis (nec ad basin aliquantum subcordatis), foliis inferioribus quam superioribus c. 2.8-plo (nec c. 4.5-plo) longioribus atque saepe anguste obovatis, foliis rosulae anguste obovatis (nec anguste ellipticis), inflorescentia rosea (nec pallide caerulea neque alba) atque ante anthesin marginem albam praebenti, corolla campanulata (nec anguste infundibulari), limbo corollae ad basin annulo percaeruleo ornato, lobis corollae uniformiter coloratis nec albo-vittatis, antheris ato-caeruleis (nec pallidis) it filamentis atroroseis (nec pallidis) differt.

Description: Shrub up to $2.4 \mathrm{~m}$, erect, densely strigose. Stems branched; bark papery silvery-white. Leaves green to pale green above, silvery-green below, smooth to touch, fur-like under magnifying lenses and silk-like under the naked-eye, densely strigose with appressed hairs only, some to many appressed hairs with expanded pustular bases especially in the adaxial face, pustular bases frequently white but sometimes translucid with concentric rows of circular cells; petiole densely hairy; veins prominent and very densely hairy in the abaxial face, very densely hairy in the adaxial face only towards the base. Longitudinal outline of leaf set broadly angular-ovate, with upper sides straight. Upper leaves of the fertile stem (Figs. $1 \mathrm{a} ; 2 \mathrm{~d}$ ) $2.6-4.3 \times 0.4-0.8 \mathrm{~cm}$, frequently of similar length as lateral cymes, narrowly ovate and rarely narrowly triangular, lingulate, leaf-apices acute, leaf-bases sessile or subsessile; leaves at the base of the cyme more or less straight but deflexed by the petiole becoming perpendicular or erect towards the base of the stem (Figs. $1 \mathrm{a} ; 2 \mathrm{~d}$ ). Lower leaves of the fertile stem (Fig. 1 a) 7.1$10.6 \times 1.4-2.2 \mathrm{~cm}$, c. $2.8 \times$ longer than upper leaves, loosely crowded, narrowly obovate to narrowly elliptical, tapering gradually but more deeply to the stalk, leaf-apices acute to shortly acuminate, leaf-base subsessile to shortly petiolate. Rosette leaves (Fig. $1 \mathrm{~b}$ ) 8.0-16.9 $\times 2.3-3.4 \mathrm{~cm}$ narrowly obovate and tapering gradually but more deeply to the stalk, leaf-apices acute to shortly acuminate, leaf-base subsessile to shortly petiolate. Inflorescence (Figs. 1 a; 2 c, d) dense, $4-23 \mathrm{~cm}$, thyrsoid, pink, top viewing of a white rim of flowers before complete anthesis; lateral cymes simple or bifid; flowers shortly pedunculated; basal bracts leaf-like in length. Calyx 6.2-9.0 $\mathrm{mm}$ in flower, densely hirsute to hispid; lobes 4.4-6.6 × 1.4-2.1 mm, narrowly ovate, green, persistent, spreading in fruit, accrescent, acute; veins blackish green, prominent. Corolla 8.9-10.1 mm, bell-shaped (Fig. $1 \mathrm{c}$ ), tinged of very pale blue or white (Fig. 2 c, d) with darker blue ring near the base of the tube, slightly pubescent on outer surface (Fig. 1 c); lobes (Fig. 1 c) 2.8-4.6 $\times 2.3$ $3.5 \mathrm{~mm}$ broadly angular-ovate, slightly pubescent on the outer surface, obtuse to rounded at the apex, constricted at the base; tube 6.2-6.9 mm, conical (Fig. $1 \mathrm{c}$ ); annulus continuous with no clear-cut but conspicuous membranous-leafy lobes (Fig. 1 d). Stamens (Figs. 1 c; 2 c, d) exerted, anthers deep blue, filaments deep pink, glabrous. Style (Figs. 1 c; 2 c, d) exerted, pale pink, somewhat setose near the base, shortly bifid. Nutlets 2.2-3.2 × 1.3-2.1 mm, dark brown, glabrous, assymetrical, laterally finelly tuberculated; conical conspicuous tubercules few numbered, occasionally two conspicuous conical tubercules on one side and one conspicuous conical tubercule on the other side.

Type: Portugal, Madeira, Porto Santo, Pico Branco, $395 \mathrm{~m}$ a.s.1., 09.III.2008, J.A. Carvalho E L. Spinola (holotype, MADJ 010478; isotype, MADJ 010480).

Derivation: After the name of the island where this species grows.

Additional material examined: See Appendix 1.

Common name: Massaroco.

Habitat and distribution: Island of Porto Santo (Madeira Archipelago). Two known localities at 200$450 \mathrm{~m}$ a.s.l. on Pico Branco and at $450 \mathrm{~m}$ a.s.l. on Pico da Gandaia, next to Pico do Facho (Fig. 3 a).

\section{Taxonomic remarks}

Our first field observations of specimens of $E$. portosanctensis were based on plants found on Pico Branco. 

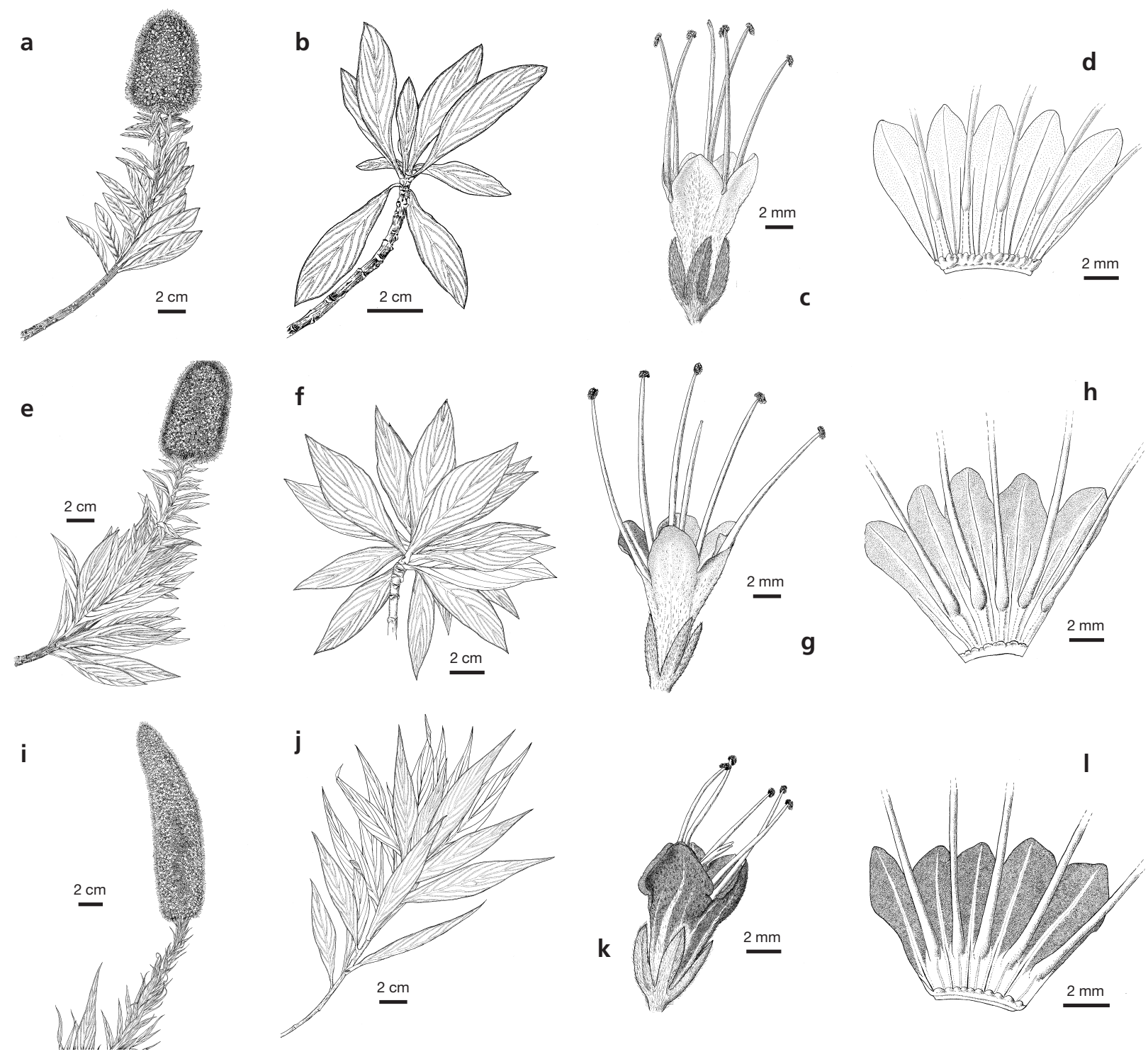

Fig. 1. Echium portosanctensis: a, inflorescence; b, rosette; c, flower; $\mathbf{d}$, annulus. E. nervosum: e, inflorescence; f, rosette; g, flower; $\mathbf{h}$, annulus. E. candicans: i, inflorescence; j, rosette; $\mathbf{k}$, flower; I, annulus. (Drawings by Helena Encarnação).

These plants had a distinct morphology from the two other Madeiran endemics. Distinct traits not found in E. candicans and E. nervosum include the pink inflorescence with a white rim of unopened flowers prior to anthesis (Fig. 2 c), very long upper leaves and lower bracts (Figs. 1 a, 2 d), leaves frequently obovate in shape (Fig. $1 \mathrm{a}, \mathrm{b})$, and silvery-green to greyish-white leaf-surface (Fig. 2 d). In opposition to the blue inflorescences without a white rim of unopened flowers, much shorter upper leaves and basal bracts (Figs. 1 e, 2 e), elliptical leaves (Fig. 1 e, f), and frequently pale-green leaf-surface found in E. nervosum. Echium candicans shows deep blue to violet inflorescence without a rim of unopened flowers (Fig. $2 \mathrm{f}$ ), much shorter upper leaves and basal bracts (Fig. 1 i), elliptical to obovate leaves
(Fig. 1 j), and green to dark green leaf-surface. Further morphological studies revealed a final set of distinguishing and diagnostic characters that differentiate $E$. portosanctensis from the other two Madeiran taxa confirming it status as a distinct species (Table 1).

Interestingly, leaf-shape of E. portosanctensis varies from elliptical to frequently obovate (Fig. $1 \mathrm{a}, \mathrm{b}$ ). This character state was not observed by Bramwell (1972), who reported that lamina of Echium species varies in shape from linear to ovate.

The structure and distribution of trichomes in $E$. nervosum, E. portosanctensis and E. candicans shows largely the same pattern observed by Bramwell (1972) for Macaronesian species of Echium. All three Madeiran species show two out of three basic forms of tri- 
chomes, namely simple hairs with small bases and large stiff setae with pustular bases. However, our micromorphological observations suggest that the Madeiran taxa had considerable variation concerning trichome size and angle of growth resulting in three types of indumenta: (1) spinous (Fig. 4 a, b), (2) appressed silky (Fig. 4 c), and (3) dense ascending to erect with long trichomes with small bases (Fig. 4 d). These type of indumenta seem to have different adaptative value. A feature that was already suggested by Bramwell (1972) for the Canary Island species of the genus. Echium portosanctensis shows an altitudinal intermediate position in relation to the other two Madeiran species. Porto Santo endemic has appressed silky indumentum contrasting with the spinous indumentum, frequently found in the low altitude sea-cliff species, E. nervosum, and the long erect hairs in the high altitude forest-cliff species, E. candicans.

Flowers have been an important source of characters for delimitation or grouping of Echium species. The annulus, a ring of tissue at the base of the corolla, was considered by Bramwell (1972) to be of great im- portance in species delimitation at section level. The usefulness of this character is clearly observed in Madeiran taxa. Echium portosanctensis presents annulus with no clear-cut but conspicuous membranous-leafy lobes (Fig. $1 \mathrm{~d}$ ) that contrasts with no clearcut and inconspicuous lobes in E. nervosum (Fig. $1 \mathrm{~h}$ ) and with the ten well defined lobes found in E. candicans (Fig. 1 1). Our observations disagree with Bramwel's (1972) reports about the presence of ten pronounced lobes in E. nervosum but agree in resolution and number of lobes of E. candicans.

E. portosanctensis shows a bell-shaped corolla (Fig. 1 c) in opposition to a funnel-shaped in the other two species (Fig. $1 \mathrm{~g}, \mathrm{k}$ ). The base of the corolla shows a darker blue ring which is not present in either E. candicans or E. nervosum. In addition, the white stripe down the middle of each lobe present on both $E$. candicans and E. nervosum is not found in E. portosanctensis.

Echium portosanctensis has deep pink anthers and deep blue filaments (Figs. 2 c, d), in opposition to the pale cream or pale pink anthers and pale pink or whitish translucid filaments of E. nervosum (Fig. 2 e)
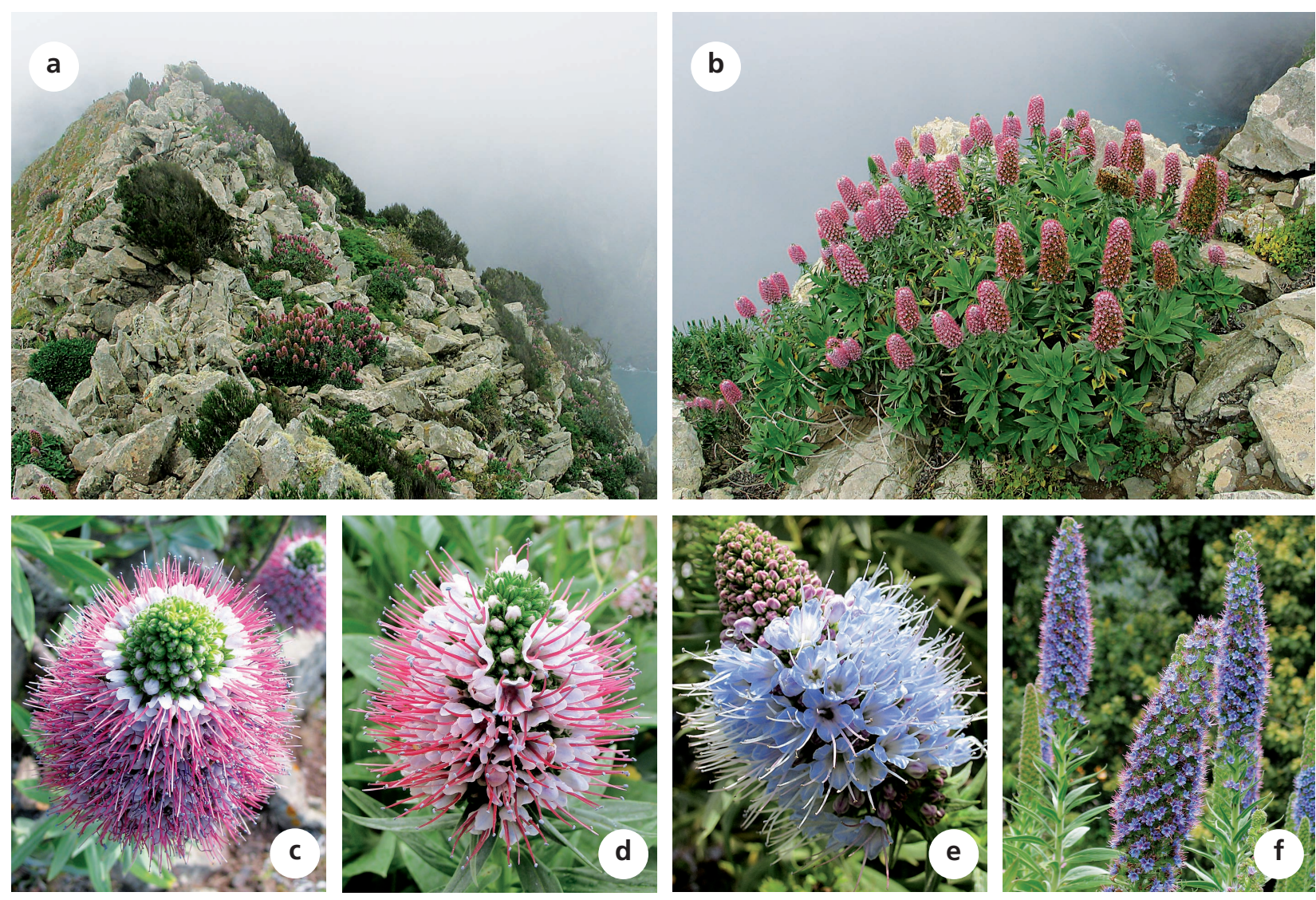

Fig. 2. Echium portosanctensis: a, habitat (Porto Santo: Pico Branco); b, habit; $\mathbf{c}$, detail of the inflorescence, namely the white rim of unopened flowers prior to anthesis; $\mathbf{d}$, detail of the inflorescence, namely deep pink filaments, deep blue anthers, long upper leaves. E. nervosum: e, inflorescence. E. candicans: $\mathbf{f}$, inflorescence. 

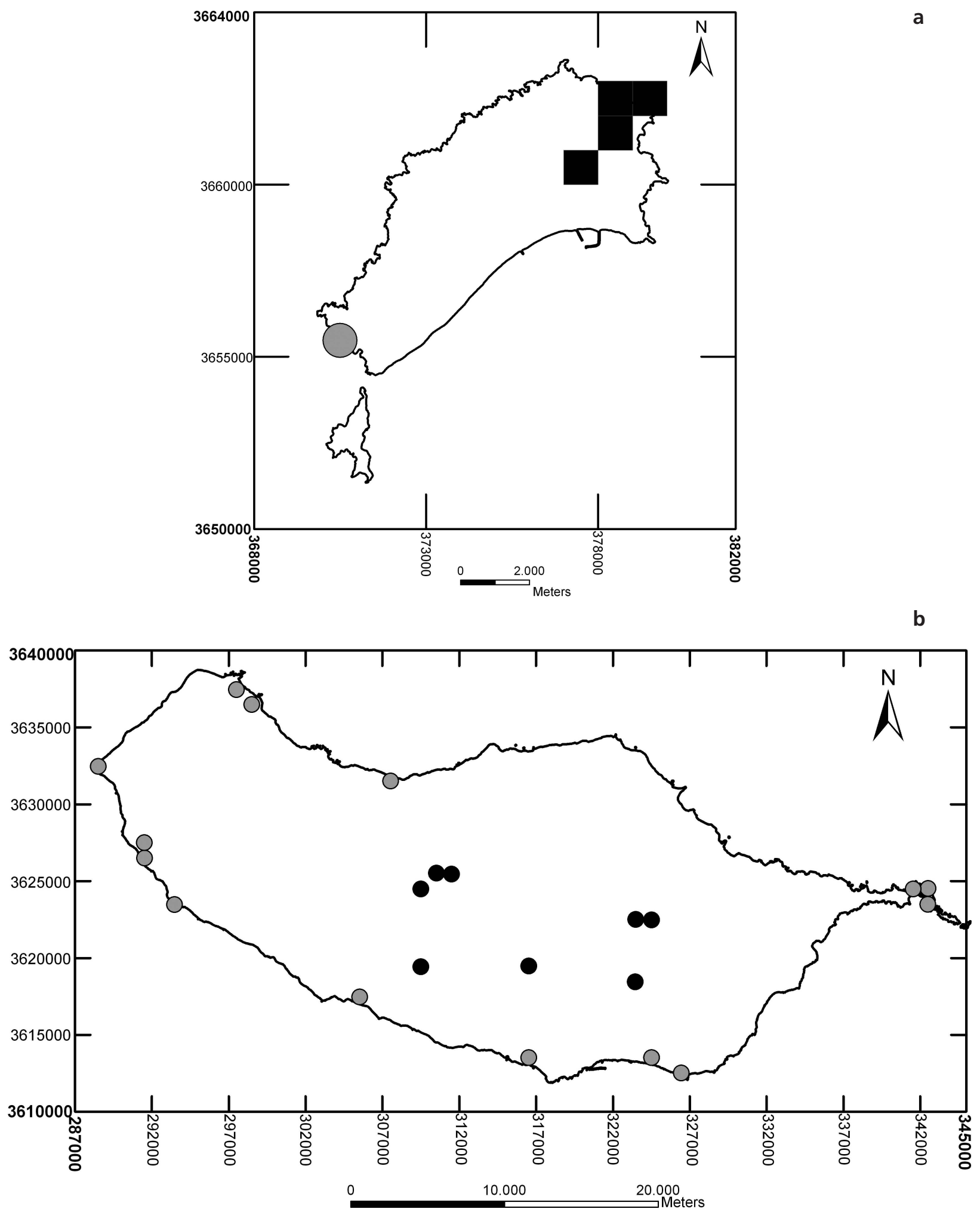

E. portosanctensis

E. candicans

E. nervosum

Fig. 3. Distribution of studied specimens of Echium portosanctensis, E. nervosum and E. candicans using a 1 km² U.T.M. grid: a, Porto Santo; b, Madeira. 
Table 1. Diagnostic characters of Echium portosanctensis vs. E. nervosum and E. candicans.

\begin{tabular}{|c|c|c|c|}
\hline Characters & E. portosanctensis & E. nervosum & E. candicans \\
\hline $\begin{array}{l}\text { Fertile stem lower leaves } \\
\text { vs. upper leaves }\end{array}$ & $\begin{array}{l}\text { Lower leaves c. } 2.8 \times \text { longer } \\
\text { than upper-leaves }\end{array}$ & $\begin{array}{l}\text { Lower leaves c. } 4.5 \times \text { longer } \\
\text { than upper-leaves }\end{array}$ & $\begin{array}{l}\text { Lower leaves c. } 5.3 \times \text { longer } \\
\text { than upper-leaves }\end{array}$ \\
\hline Leaf colour & $\begin{array}{l}\text { Pale green to silvery-green } \\
\text { in the adaxial face } \\
\text { Greyish-white to silvery } \\
\text { in the abaxial face }\end{array}$ & $\begin{array}{l}\text { Green but very rarely pale } \\
\text { green in the adaxial face } \\
\text { Pale green but very rarely } \\
\text { silvery-green in the abaxial face }\end{array}$ & $\begin{array}{l}\text { Dark green in the adaxial face } \\
\text { Green in the abaxial face }\end{array}$ \\
\hline Limb indumentum & $\begin{array}{l}\text { Densely strigose } \\
\text { Some to many close-pressed } \\
\text { hairs with expanded white but } \\
\text { sometimes translucid bases, } \\
\text { especially in the adaxial face }\end{array}$ & $\begin{array}{l}\text { Densely strigose but with some } \\
\text { to many stiff and erect hairs } \\
\text { Some to many erect hairs with } \\
\text { expanded white but sometimes } \\
\text { translucid bases, especially in } \\
\text { the adaxial face }\end{array}$ & $\begin{array}{l}\text { Finely and densely hispid } \\
\text { Hairs with or without } \\
\text { expanded white bases }\end{array}$ \\
\hline Leaf texture & $\begin{array}{l}\text { Smooth to touch } \\
\text { Silky look }\end{array}$ & Harsh to the touch & Velvet-like to touch \\
\hline Leaf apex & Acute to shortly acuminate & Acute to shortly acuminate & Long acuminate \\
\hline $\begin{array}{l}\text { Fertile stem upper } \\
\text { leaves size }\end{array}$ & $\begin{array}{l}2.6-4.3 \mathrm{~cm} \\
\text { Similar length as basal } \\
\text { lateral cymes }\end{array}$ & $\begin{array}{l}0.6-2.7 \mathrm{~cm} \\
\text { Much smaller than basal } \\
\text { lateral cymes }\end{array}$ & $\begin{array}{l}2.2-4.5 \mathrm{~cm} \\
\text { Much longer than basal } \\
\text { lateral cymes }\end{array}$ \\
\hline $\begin{array}{l}\text { Fertile stem upper leaves } \\
\text { and basal bracts shape }\end{array}$ & $\begin{array}{l}\text { Narrowly ovate and rarely } \\
\text { narrowly triangular } \\
\text { Always lingulate }\end{array}$ & $\begin{array}{l}\text { Narrowly triangular } \\
\text { to narrowly ovate } \\
\text { Somewhat subcordate } \\
\text { at the base }\end{array}$ & $\begin{array}{l}\text { Narrowly triangular } \\
\text { Somewhat lingulate } \\
\text { Subcordate at the base }\end{array}$ \\
\hline Rosette leaf shape & Narrowly obovate & Narrowly elliptical & Elliptical to obovate \\
\hline Inflorescence size & Up to $23 \mathrm{~cm}$ & Up to $23 \mathrm{~cm}$ & Up to $47 \mathrm{~cm}$ \\
\hline Inflorescence colour & Pink & Pale blue or white & Deep blue to violet \\
\hline Inflorescence shape & Thyrsoid & Thyrsoid & Spiciform \\
\hline $\begin{array}{l}\text { Inflorescence white } \\
\text { rim of unopened flowers }\end{array}$ & Present & Absent & Absent \\
\hline Corolla shape & Bell-shaped with conical tube & Narrowly funnel-shaped & Narrowly funnel-shaped \\
\hline Corolla colour & $\begin{array}{l}\text { White, white-bluish or tinged } \\
\text { of very pale blue with darker } \\
\text { blue ring near the tube base }\end{array}$ & $\begin{array}{l}\text { Pale blue with a white stripe } \\
\text { down the middle of each lobe, } \\
\text { or more rarely completely white }\end{array}$ & $\begin{array}{l}\text { Blue to violet, often with a } \\
\text { white stripe on each lobe }\end{array}$ \\
\hline Annulus & $\begin{array}{l}\text { No clear-cut but conspicuous } \\
\text { membranous-leafy lobes }\end{array}$ & $\begin{array}{l}\text { No clear-cut and } \\
\text { inconspicuous lobes }\end{array}$ & $\begin{array}{l}\text { Up to } 10 \text { clear-cut } \\
\text { conical lobes }\end{array}$ \\
\hline Corolla lobes base & Constricted & Constricted & Constricted-auriculate \\
\hline Calyx colour & Green & Dark green & Dark green \\
\hline Calyx prominent black veins & Present & Absent & Absent \\
\hline Filaments colour & Intense pink & Pale pink or whitish translucid & Pink \\
\hline Anthers colour & Intense blue & Pale blue or pale cream & Pale cream \\
\hline Nutlets texture & Smooth & $\begin{array}{l}\text { Mature seeds whitish } \\
\text { reticulate-papillated }\end{array}$ & Smooth \\
\hline Nutlets colour & Dark brown & Light brown & Dark brown \\
\hline
\end{tabular}



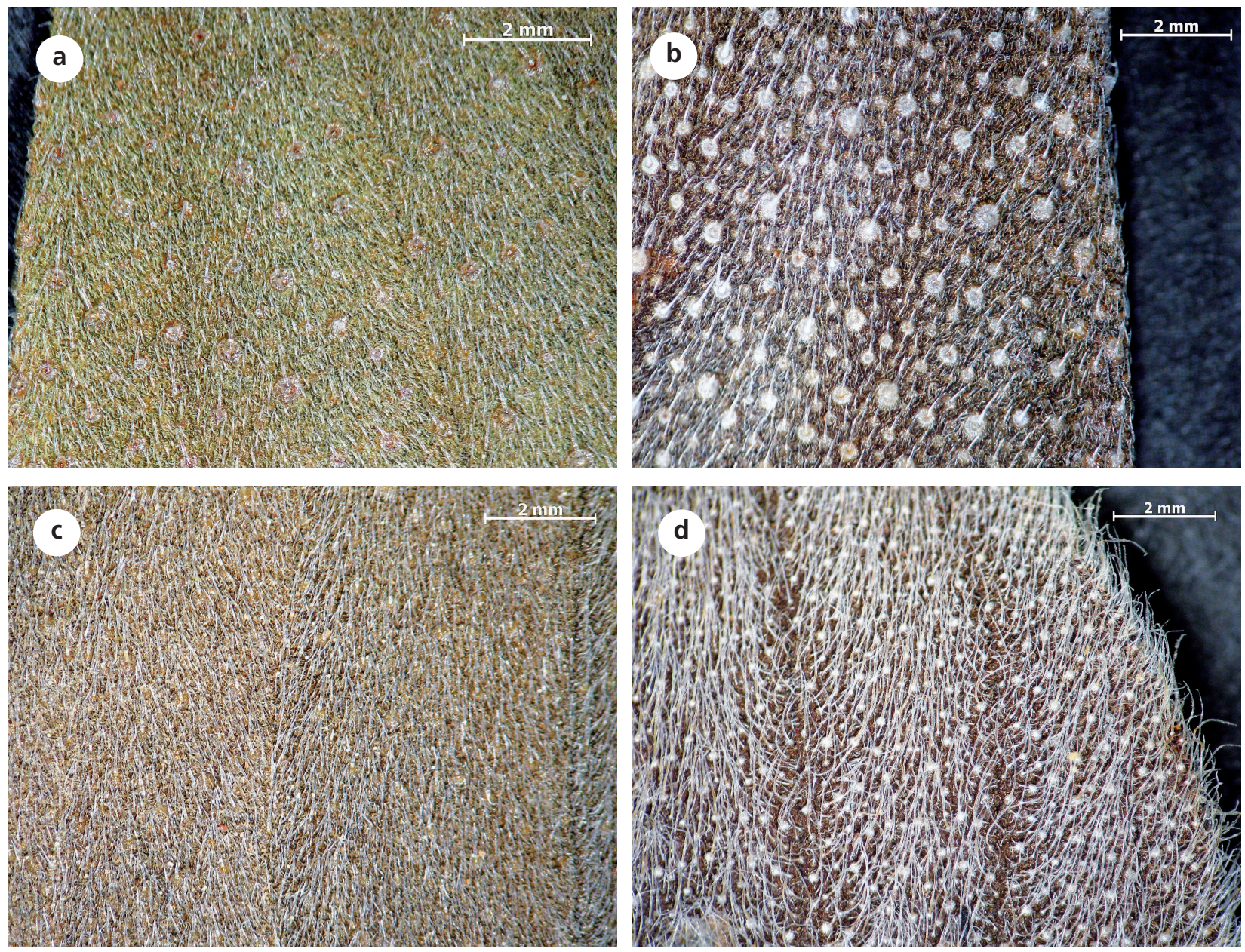

Fig. 4. Detail on upper leaf surface: $\mathbf{a}, \mathbf{b}$, variation in Echium nervosum [MADJ 10497] with short appressed and erect trichomes; c, E. portosanctensis [MADJ 10479] with short appressed trichomes only; d, E. candicans [MADJ 08189] with long erect trichomes.

and the pale cream anthers and pink filaments of E. candicans (Fig. $2 \mathrm{f}$ ). The distinctive pink colour of the inflorescence in E. portosanctensis is given by the override of the intense pink colour of the exerted filaments in relation to the white to very pale blue colour of the corolla. Andrada (1974) referred to a yellowish inflorescence colour in E. portosanctensis that can be observed in the photograph included in his publication. However, this colour type was never found in our field studies and was not reported by Jardim \& al. (1998) either, therefore, we presume the yellowish inflorescence to be the result of a photographic artefact.

E. portosanctensis shows overall closer morphological similarities to E. nervosum than to E. candicans (Table 1), namely the densely strigose indumentum, the thyrsoid shape of the inflorescence and its short size, the acute to shortly acuminate leaf-apice, leaf-colour, constriction of corolla lobes and no clear-cut annulus lobes.

\section{KEY TO MADEIRAN ECHIUM SPECIES}

1. Plant with long spreading hairs. Inflorescence spiciform. Leaves long acuminate

\section{E. candicans}

Plant mostly with short appressed hairs. Inflorescence thyrsoid. Leaves acute to shortly acuminate

2. Fertile stems with lower leaves c. 4.5 times longer than upper leaves. Leaves densely strigose but with some to many stiff and erect hairs. Inflorescence blue or white. Anthers pale blue. Filaments light pink or translucid ....... 2. E. nervosum

3. Fertile stems with lower leaves c. 2.8 times longer than upper leaves; leaves densely strigose with appressed hairs only; inflorescence pink, anthers deep blue, filaments deep pink ....

E. portosanctensis

\section{Remarks on the distribution and ecology of}

\section{E. portosanctensis, E. candicans and E. nervosum}

E. portosanctensis occurs on areas influenced by sea winds, namely on the northern steep rocky areas and northwestern slopes of Pico Branco (Fig. 2 a), and top 
southern slopes of Pico da Gandaia, but also on the drier and warmer south-eastern slopes of Pico Branco. This species belongs to the alliance Mayteno umbellatae-Oleion maderensis Capelo, J.C. Costa, Lousã, Fontinha, Jardim, Sequeira \& Rivas-Martínez. Echium candicans is common and grows in the upper limits of the laurel forest and in the high altitudes heaths. It also can be found on ravine cliffs of the high elevation mountains in central Madeira (Fig. 3 b). This species is characteristic of the alliance Bystropogono punctatiTelinion maderensis Capelo, J.C. Costa, Lousã, Fontinha, Jardim, Sequeira \& Rivas-Martínez (Costa, 2004). Echium nervosum is common in the coastal regions of Madeira, particularly in the south, growing on sea cliffs, dry rocky slopes and along road sides, between 0 and $300 \mathrm{~m}$ a.s.l (Fig. 3 b). It also grows at Zimbralinho, a dry and small valley at the southwest coastal region of Porto Santo island (Fig. 3 a). On the islands of Desertas, this species is restricted to the north of the island of Bugio (Costa-Neves, 1992). This species is typical of the alliance Mayteno umbellatae-Oleion maderensis Capelo, J.C. Costa, Lousã, Fontinha, Jardim, Sequeira \& Rivas-Martínez (Costa, 2004).

\section{Conservation status of Echium portosanctensis}

This species is extremely rare with a reduced distribution (Fig. 3 a), small population size, and only known at two sites on the island of Porto Santo, i.e. Pico Branco and Pico da Gandaia.

E. portosanctensis is classified under the IUCN red list categories of threat (2001) as Vulnerable (VU$\mathrm{D} 1 / 2$ ) on the basis of its small population size estimated to number fewer than 1000 mature individuals but also due to its population very restricted distribution area (less than $4 \mathrm{~km}^{2}$ ) and the very reduced number of populations (two). These criteria, according to IUCN (2001), are sufficient to consider this species to be prone to the effects of human activities or stochastic events within a very short time period in an uncertain future. Echium portosanctensis has an added risk for extinction arising from hybridisation with a introduced species of Echium, namely E. nervosum from Madeira, and subsequent introgression events that are capable of turning E. portosanctensis into a Critically Endangered or even Extinct species.

\section{Aknowledgements}

We thank posthumously Eng. Rui Vieira, founder and first Director of Jardim Botânico da Madeira, to whom this paper is dedicated, for providing us information on his observations and collections of Echium on Porto Santo, including letters exchanged with Alfred Hansen. Thanks are due to Madeira Department of Fores- try, Madeira General Office of Education, University of Madeira Centre for Macaronesian Studies and Science and Technology Foundation (FCT, Portugal) who provided financial support through the multi-annual but also through the Praxis XXI Programme funding. We are specially grateful to forestry police on the island of Porto Santo, Madeira Botanical Garden technicians for their invaluable help in collecting and processing specimens, Nuno Serralha for mapping species distribution, Melanie Thomas for diagnosis translation and Javier Francisco-Ortega for English revision of this article.

\section{References}

Andrada, E.C.1974. Contribuição dos serviços florestais na preservação da flora da Madeira. Secretaria de Estado da Agricultura. Lisboa.

Böhle, U.-R., Hilger, H.H. \& Martin, W.F. 1996. Island colonization and evolution of the insular woody habit in Echium L. (Boraginaceae). Proceedings of the National Academy of Sciences of the United States of America 93: 11740-11745.

Bramwell, D. 1972. A revision of the genus Echium in Macaronesia. Lagascalia 2(1): 37-115.

Costa, J.C., Capelo, J., Jardim, R., Sequeira, M., Espirito-Santo, D., Lousã, M., Fontinha, S., Aguiar, C. \& Rivas-Martinez, S. 2004. Catálogo sintaxonómico e florístico das comunidades vegetais da Madeira e Porto Santo. Quercetea 6: 61-185.

Costa, J.G. 1946. Lista Fitológica do Porto Santo. Boletim do Museu Municipal do Funchal 2(4): 65-71.

Costa-Neves, H., Silva, I. \& Palmeira, C. 1992. Contributions to the knowledge of the flora of Desertas Islands. Bocagiana 163: $1-21$.

García-Maroto, F., Mañas-Fernández, A., Garrido-Cárdenas, J.A., Alonso, D.L., Guil-Guerrero, J.L., Guzmán, B., Vargas, P. 2009. D6-Desaturase sequence evidence for explosive Pliocene radiationswithin the adaptive radiation of Macaronesian Echium (Boraginaceae). Molecular Phylogenetics and Evolution 52: $563-574$

Hansen, A. 1969. Checklist of the vascular plants of the archipelago of Madeira. Boletim do Museu Municipal do Funchal 24: $5-62$.

IUCN. 2001. IUCN Red List Categories: version 3.1. Prepared by the IUCN Species Survival Comission. IUCN. Gland, Switzerland and Cambridge.

Jardim, R., Fontinha, S. \& Fernandes, F. 1998. Pico Branco: a peculiar floristic site on Porto Santo island. Boletim do Museu Municipal do Funchal 50(285): 43-57.

Jardim, R. \& Sequeira, M.M. 2008. List of vascular plants (Pteridophyta and Spermatophyta). In: Borges, P.A.V., Abreu, C., Aguiar, A.M.F., Carvalho, P., Jardim, R., Melo, I., Oliveira, P., Sérgio, C., Serrano, A.R.M. \& Vieira, P. (eds.), A list of the terrestrial fungi, flora and fauna of Madeira and Selvagens archipelagos: 179-207. Direcção Regional do Ambiente da Madeira e Universidade dos Açores. Funchal and Angra do Heroísmo.

Menezes, C.A. 1914. Flora do Archipelago da Madeira (Phanerogamicas e Cryptogamicas Vasculares). Typ. Bazar do Povo. Funchal.

Pickering, C.H.C. 1962. A Checklist of the flowering plants and ferns of Porto Santo (Archipelago of Madeira). Boletim do Museu Municipal do Funchal 15: 33-60.

Santos, A. 1983. Vegetación y flora de La Palma. Interinsular Canaria. Santa Cruz de Tenerife.

Short, M.J. 1994. Boraginaceae. In: Press, J.R. \& Short, M.J. (eds.), Flora of Madeira 276-277. HMSO. London. 


\section{Appendix 1}

\section{Studied material}

\section{Echium candicans L.f., Suppl. pl.: 131. 1782}

PORTUGAL. Madeira island: Ribeiro Frio, VII.1927, Barreto (MADJ 878); Ribeiro Frio, VII.1927, Barreto (MADJ 879); Madeira, São Vicente, Posto Florestal da Encumeada, 30.V.1986, Fontinha \& Baeta (MADJ 09650); Vereda Pico do Areeiro - Pico Ruivo, 23.VI.2009, R. Jardim (MADJ 10709); Origem da Levada da Ponta do Sol, Encumeada - Rabaças, 17.V.1988, Nóbrega (MADJ 06529); Levada do Ribeiro Frio na Quebrada Azeda, 16.VI.1994, Nóbrega (MADJ 08199); Levada do Norte: zona do Espigão da Ribeira Brava, 22.II.1982, Nóbrega, R. Santos, D. Noia, Pita (MADJ 03892); Levada do Norte: zona do Espigão da Serra de Água, 21.IV.1982, Nóbrega, R. Santos, D. Noia, Pita (MADJ 03893); Quinta do Bom Sucesso, 16.I.1958, R. Santos (MADJ 03890); Eira do serrado, 17.VI.1971, C. Simon (MADM 1863).

\section{Echium nervosum Dryand. in W.T. Aiton, Hortus kew, Ed. 2, 1:300. 1810}

PORTUGAL. Madeira island: Praia Formosa, 24.IV.2001, J.A. Carvalho (MADJ 10257); Ribeira do Inferno, antiga estrada regional, junto ao túnel de água d'alto da via expresso, 30.V.2008, J.A. Carvalho (MADJ 10470); Ribeira do Inferno, antiga estrada regional, junto ao túnel de água d'alto da via expresso, 30.V.2008, J.A. Carvalho (MADJ 10471); Paul do Mar, 29.II.2008, J.A. Carvalho (MADJ 10484); Paul do Mar, 29.II.2008, J.A. Carvalho (MADJ 10485); Paul do Mar, 29.II.2008, J.A. Carvalho (MADJ 10486); Paul do Mar, 29.II.2008, J.A. Carvalho (MADJ 10487); Paul do Mar, 29.II.2008, J.A. Carvalho (MADJ 10489); Paul do Mar, 29.II.2008, J.A. Carvalho (MADJ 10490); Fajã da Ovelha, 29.II.2008, J.A. Carvalho (MADJ 10491); Garajau, logo no início da descida para a praia do Garajau, 27.III.2008, J.A. Carvalho (MADJ 10493); Garajau, logo no início da descida para a praia do Garajau, 27.III.2008, J.A. Carvalho (MADJ 10494); Garajau, logo no início da descida para a praia do Garajau, 27.III.2008, J.A. Carvalho (MADJ 10495); Garajau, logo no início da descida para a praia do Garajau, 27.III.2008, J.A. Carvalho (MADJ 10496); Ponta de São Lourenço, Estreito, 28.IV.2008, J.A. Carvalho (MADJ 10503); Ponta de São Lourenço, Estreito, 28.IV.2008, J.A. Carvalho (MADJ 10504); Ponta de São Lourenço, Estreito, 28.IV.2008, J.A. Carvalho (MADJ 10505); Ponta do Pargo, junto ao farol, 27.III.2008, J.A. Carvalho (MADJ 10506); Ponta do Pargo, junto ao farol, 29.IV.2008, J.A. Carvalho (MADJ 10507); Ponta do Pargo, junto ao farol, 27.III.2008, J.A. Carvalho (MADJ 10508); Ponta do Pargo, junto ao farol, 27.III.2008, J.A. Carvalho (MADJ 10509); Ponta do Pargo, junto ao farol, 27.III.2008, J.A. Carvalho (MADJ 10510); Praia Formosa, IV.1923, Costa (MADJ 881); Ponta de São Lourenço, na encosta acima da Casa do Sardinha, 3.III.2008, J.A. Carvalho \& L. Spínola (MADJ 10497); Ponta de São Lourenço, na encosta acima da Casa do Sardinha, 3.III.2008, J.A. Carvalho \& L. Spínola (MADJ 10498); Ponta de São Lourenço, na encosta acima da Casa do Sardinha, 3.III.2008, J.A. Carvalho \& L. Spínola (MADJ 10499); Ponta de São Lourenço, na encosta acima da Casa do Sardinha, 3.III.2008, J.A. Carvalho \& L. Spínola (MADJ 10500); Ponta de São Lourenço, na encosta acima da Casa do Sardinha, 3.III.2008, J.A. Carvalho \& L. Spínola (MADJ 10501); Ponta de São Lourenço, na encosta acima da Casa do Sardinha, 3.III.2008, J.A. Carvalho \& L. Spínola (MADJ 10502); Ponta de São Lourenço, na encosta acima da Casa do Sardinha, 3.III.2008, J.A. Carvalho \& L. Spínola (MADJ 10511); Entre o Garajau e o Pináculo, à beira-mar, 1.VI.1991,
Fontinha \& J. Carvalho (MADJ 02727); Tabua, em rochas junto ao mar, 7.IV.1973, A. Hansen (MADJ 03895); Ribeira da Janela, 6.V.1999, R. Jardim \& J.A. Carvalho (MADJ 10697); Ribeira do Inferno, São Vicente, 6.V.1999, R. Jardim \& J.A. Carvalho (MADJ 10698); Praia Formosa, Funchal, 27.V.1999, R. Jardim \& J.A. Carvalho (MADJ 10699); Paul do Mar, 6.V.1999, R. Jardim \& J.A. Carvalho (MADJ 10701); Porto Moniz, 26.V.1999, R. Jardim \& J.A. Carvalho (MADJ 10703); Porto Moniz, 6.V.1999, R. Jardim \& J.A. Carvalho (MADJ 10704); Ponta do Pargo, Madeira, 6.V.1999, R. Jardim \& J.A. Carvalho (MADJ 10705); Ponta de São Lourenço, 20.V.1999, R. Jardim \& J.A. Carvalho (MADJ 10706); 02.IV.1888, Kuntze (K); Praia Formosa, 20.IV.1966, K. Lems 7478 (K); Lowe (K); 1865, G. Mandon 183 (K); Ilhéu dos Desembarcadouros, 19.V.1983, Nóbrega (MADJ 03898); São Vicente, 6.XII.1984, Nóbrega, Pita, R. Santos (MADJ 03899); Jardim do Mar, 25.IV.2001, T. Pontes \& J.A. Carvalho (MADJ 10702); Ribeira Brava, 30.IV.1924, L. A. M. Riley 34 (K); Garajau, 1.VI.1977, Zeca e João (MADM 1859); Garajau, 1.VI.1977, Zeca e João (MADM 1861). Porto Santo island: Zimbralinho, 9.III.2008, J.A. Carvalho \& L. Spínola (MADJ 10468); Zimbralinho, 9.III.2008, J.A. Carvalho \& L. Spínola (MADJ 10469); Pico Castelo, 1.IV.1994, S. Fontinha (MADJ 08897); Fonte da Areia, 18.IV.2004, R. Jardim (MADJ 10707); Zimbralinho, Porto Santo, 11.IV.1999, R. Jardim \& J.A. Carvalho (MADJ 10700). Desertas islands: Bugio norte, 9.VI.1988, H. CostaNeves (MADM 1807); Bugio norte, 9.VI.1988, H. Costa-Neves (MADM 1808).

Echium portosanctensis J.A. Carvalho, Pontes, BatistaMarques \& R. Jardim

PORTUGAL. Porto Santo island: Pico Branco, 20.III.2000, J.A. Carvalho \& R. Jardim (MADJ 10246); Pico Castelo, na berma da estrada que desce do Pico do Facho, 10.III.2008, J.A. Carvalho \& L. Spínola (MADJ 10472); Pico Branco, vereda a subir para o Pico Branco, 9.III.2008, J.A. Carvalho \& L. Spínola (MADJ 10475); Pico Branco, vereda a subir para o Pico Branco, 9.III.2008, J.A. Carvalho \& L. Spínola (MADJ 10476); Pico Branco, vereda a subir para o Pico Branco, 9.III.2008, J.A. Carvalho \& L. Spínola (MADJ 10477); Pico Branco, depois do topo do Pico Branco vertente oeste, junto ao precipício, 9.III.2008, J.A. Carvalho \& L. Spínola (MADJ 10478); Pico Branco, depois do topo do Pico Branco, vertente Oeste, à entrada para o precipício, junto a uma grande urze, 9.III.2008, J.A. Carvalho \& L. Spínola (MADJ 10479); Pico Branco, depois do topo, à entrada para o precipício, junto a uma grande urze, 9.III.2008, J.A. Carvalho \& L. Spínola (MADJ 10480); Pico da Gandaia, ao lado do Pico do Facho, 455 m; exposição W, N 33º 05.042'/ W 016 19.277', 10.III.2008, J.A. Carvalho \& L. Spínola (MADJ 10481); Pico da Gandaia, ao lado do Pico do Facho, 455 m; exposição W, N $33^{\circ}$ 05.042'/ W 016 19.277', 10.III.2008, J.A. Carvalho \& L. Spínola (MADJ 10482); Pico da Gandaia, ao lado do Pico do Facho, 455 m; exposição W, N 33 05.042'/ W 016 ${ }^{\circ} 19.277^{\prime}$, 10.III.2008, J.A. Carvalho \& L. Spínola (MADJ 10483); Pico Branco, 26.III.1988, F. Fernandes \& R. Jardim (MADJ 08943); Pico Branco, Barranco das Feiteiras, 2.IV.1994, S. Fontinha (MADJ 08898); Pico Branco, 28.III.2007 (MADJ 10696); Pico Branco, 9.IV.1999, R. Jardim (MADJ 10708); Terra Chã, 27.V.1958, R. Santos (MADJ 05996); Estrada florestal do Pico Castelo, 12.IV.1977, R. Vieira (MADJ 05995); Pico Branco, no cume, 17.IX.1960, R. Vieira (MADJ 05997).
Associate Editor: E. Rico Received: 7-IX-2009 Accepted: 6-IX-2010 